\title{
STUDY OF THE PROPERTIES AND HYGROTHERMAL BEHAVIOUR OF ALTERNATIVE INSULATION MATERIALS BASED ON NATURAL FIBRES
}

\author{
ŠTUDIJ LASTNOSTI IN HIGROTERMALNO OBNAŠANJE \\ ALTERNATIVNIH IZOLACIJSKIH MATERIALOV NA OSNOVI \\ NARAVNIH VLAKEN
}

\author{
Jiří Zach, Martina Reif, Jitka Hroudová \\ Brno University of Technology, Faculty of Civil Engineering, Veveří 331/95, 60200 Brno, Czech Republic \\ zach.j@fce.vutbr.cz, reif.m@fce.vutbr.cz, hroudova.j@fce.vutbr.cz
}

Prejem rokopisa - received: 2014-08-01; sprejem za objavo - accepted for publication: 2015-03-02

doi:10.17222/mit.2014.169

\begin{abstract}
The paper describes the results of a research focused on the development of natural thermal and acoustic insulation materials. They are mainly materials based on locally available agricultural waste (mainly in the third-world countries). In particular, this waste includes stems of rice and other plants. The paper describes the behaviour of these materials under different humidity conditions and the possibility to influence their properties by varying the ratio between organic and inorganic binders. Using the results, general conditions for the suitability of the application of these materials in building constructions were defined.

Keywords: natural fibres, moisture content, thermal conductivity, rice stems, cotton stems, thermal insulation

Članek opisuje rezultate raziskav usmerjenih v razvoj naravnih materialov za toplotno in akustično izolacijo. To so pretežno materiali, ki predstavljajo lokalno dosegljive kmetijske odpadke (večinoma v tretjem svetu). To so zlasti stebla riža in drugih rastlin. Članek opisuje obnašanje teh materialov pri različnih pogojih vlažnosti in možnosti za vplivanje na njihove lastnosti pri različnih razmerjih organskih in anorganskih veziv. Na podlagi rezultatov so bili določeni splošni pogoji za primernost in uporabnost teh materialov v gradbeništvu.

Ključne besede: naravna vlakna, vsebnost vlage, toplotna prevodnost, stebla riža, stebla bombaža, toplotna izolacija
\end{abstract}

\section{INTRODUCTION}

Considering the ever-increasing demand for insulation materials, the general need for a sustainable development and an effort to limit the exploitation of raw-material sources, fibrous insulation materials based on organic fibres from agriculture (hemp, flax, waste textile fibres, rice and cotton-plant stems, sheep wool, etc.) have been developed at Brno University of Technology, Faculty of Civil Engineering, for many years. The development of these materials was also carried out with regard to the findings of foreign experts recorded in the literature in specialized databases (Thomson Reuters, Scopus). We considered the research of the scientific teams from Europe and Asia. ${ }^{1-8}$

These materials represent highly progressive building materials with a low carbon footprint and a low primary-energy input. They are locally available and easily renewable raw materials that can substitute non-renewable materials used in the production of insulation materials (e.g., foam plastic materials). In addition, the production of these materials has lower energy costs compared to the production of many modern synthetic insulators (e.g., mineral wool). The experiments performed during the previous research revealed that these materials show properties comparable with the synthetic insulation materials available on the market. ${ }^{9}$ However, in terms of the thermal-insulation properties, these natural fibre-based materials exhibit a different hygrothermal behaviour due to different structures of the insulations and also a low thermal conductivity of the natural fibres compared to the glass or mineral ones.

\section{INPUT RAW MATERIALS AND TEST MIXTURES}

For the production of specimens, alkali-activated blast-furnace slag containing $\mathrm{SiO}_{2}(42.24 \%), \mathrm{CaO}$ (44.87\%), $\mathrm{Al}_{2} \mathrm{O}_{3}(2.73 \%)$ and $\mathrm{MgO}(5 \%)$ was used with $\mathrm{Fe}_{2} \mathrm{O}_{3}, \mathrm{MnO}, \mathrm{TiO}_{2}, \mathrm{P}_{2} \mathrm{O}_{5}, \mathrm{Na}_{2} \mathrm{O}, \mathrm{K}_{2} \mathrm{O}$ and sodium water glass. Rice and cotton-plant stems were used as the organic binders. The specific quantities of the raw materials are listed in Table $\mathbf{1 .}$

Table 1: Overview of the specimen compositions

Tabela 1: Pregled sestave vzorcev

\begin{tabular}{|c|c|c|c|c|}
\hline $\begin{array}{c}\text { Mixture } \\
\text { No. }\end{array}$ & $\begin{array}{c}\text { Rice stems } \\
\left(\mathrm{kg} \mathrm{m}^{-3}\right)\end{array}$ & $\begin{array}{c}\text { Cotton } \\
\text { stems } \\
\left(\mathrm{kg} \mathrm{m}^{-3}\right)\end{array}$ & $\begin{array}{c}\text { Slag } \\
\left(\mathrm{kg} \mathrm{m}^{-3}\right)\end{array}$ & $\begin{array}{c}\text { Water glass } \\
\left(\mathrm{kg} \mathrm{m}^{-3}\right)\end{array}$ \\
\hline 1 & 100 & - & 300 & 200 \\
\hline 2 & 120 & - & 250 & 190 \\
\hline 3 & - & 100 & 300 & 200 \\
\hline
\end{tabular}




\section{METHODOLOGY}

After removing the formwork, the specimens were stored under laboratory conditions at $23 \pm 2{ }^{\circ} \mathrm{C}$ and a relative humidity of $50 \pm 5 \%$. After $28 \mathrm{~d}$, the specimens were dried and their bulk density was determined according to EN 1602. ${ }^{10}$ Subsequently, hygroscopicity was determined for the specimens stored at $+23{ }^{\circ} \mathrm{C}$ and different relative-humidity conditions. The equal-sorption humidity as well as the thermal conductivity depending on the humidity were determined. The thermal conductivity was determined at the stable state in accordance with EN $12667^{11}$ and ISO 8301. ${ }^{12}$ Acoustic properties were also determined for the specimens. Specifically, the dynamic stiffness of the material was determined in accordance with ISO $9052-1^{13}$ and the sound-absorption coefficient was determined in accordance with EN ISO $11654^{14}$ and ISO 10534-1..$^{15}$

\section{RESULTS AND DISCUSSION}

The bulk density was determined for the samples in the dried state in accordance with EN $1602^{10}$ and the specific values are shown in Table 2.

Table 2: Summary of individual bulk densities $\rho_{\mathrm{v}}$ of the specimens Tabela 2: Pregled posameznih gostot $\rho_{\mathrm{v}}$ vzorcev

\begin{tabular}{|c|c|c|c|}
\hline Mixture No. & 1 & 2 & 3 \\
\hline$\rho_{\mathrm{v}}\left(\mathrm{kg} \mathrm{m}^{-3}\right)$ & 440 & 430 & 430 \\
\hline
\end{tabular}

The average bulk density ranged from $430 \mathrm{~kg} \mathrm{~m}^{-3}$ to $440 \mathrm{~kg} \mathrm{~m}^{-3}$ and its values for different fillers in mixtures 1 and 3 were also comparable. Next, the moisture content under laboratory conditions was determined. The samples were stored in the laboratory, at the temperature of $23{ }^{\circ} \mathrm{C}$ and the relative humidity of $50 \%$ and were subsequently dried at a temperature of $105{ }^{\circ} \mathrm{C}$. Afterwards, the natural-moisture content prior to drying was measured using the gravimetric method. The resulting values are shown in Figure 1.

The natural-water content of a material depends on the amount of the pores present in the material, their

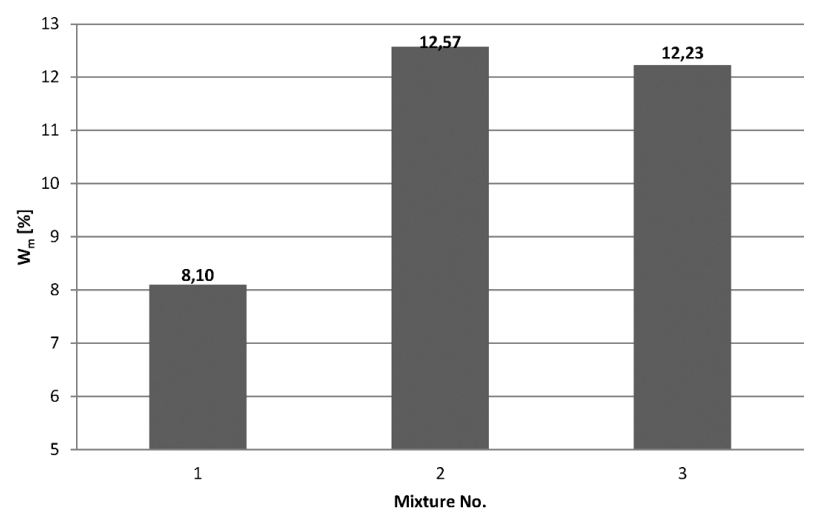

Figure 1: Natural-moisture content $\left(w_{\mathrm{m}} / \%\right)$

Slika 1: Vsebnost naravne vlage $\left(w_{\mathrm{m}} / \%\right)$ size, openness and the degree to which they are interconnected. The pore system depends on the compaction during the production, the amount of inorganic binders and the choice of organic fillers. It is clear from the graph that the cotton-stem sample has a higher natural moisture than the specimen with the same amount of rice stems. Increasing their amounts also increases the natural moisture. In addition, hygroscopicity of the specimens was determined. The specimens were stored in the environments with the following parameters:

- in laboratory conditions - a relative humidity of $50 \%$ and a temperature of $23{ }^{\circ} \mathrm{C}$

- in humid conditions - a relative humidity of $95 \%$ and a temperature of $23{ }^{\circ} \mathrm{C}$

The amounts of the moisture absorbed by the specimens into their structures are listed in Table 3.

Table 3: Summary of measured moistures $w_{\mathrm{m}}$ at varied relative humidity $\varphi$ and temperature of $+23{ }^{\circ} \mathrm{C}$

Tabela 3: Povzetek izmerjenih vlažnosti $w_{\mathrm{m}}$ pri spreminjanju relativne vlažnosti $\varphi$ in temperaturi $+23{ }^{\circ} \mathrm{C}$

\begin{tabular}{|c|c|c|c|}
\hline \multirow{2}{*}{$\varphi / \%$} & Mixture No. 1 & Mixture No. 2 & Mixture No. 3 \\
\cline { 2 - 4 } & \multicolumn{3}{|c|}{$w_{\mathrm{m}} / \%$} \\
\hline 0 & 0 & 0 & 0 \\
\hline 50 & 8.10 & 12.57 & 12.23 \\
\hline 95 & 33.04 & 47.00 & 42.11 \\
\hline
\end{tabular}

A sorption curve was constructed from the obtained data. The determination of the sorption isotherm was carried out at $23{ }^{\circ} \mathrm{C}$. The moisture content of the specimens was measured at the relative-humidity levels of 50 and $95 \%$. The results of the measurement are shown in Figure 2.

The amount of the absorbed moisture depends on the structure of the given material, the temperature and the relative humidity of the environment, to which the material is exposed. With its growing value, the moisture content in the material rises nonlinearly.

In the next stage, the thermal conductivity in dependence on the specimen moisture was determined in

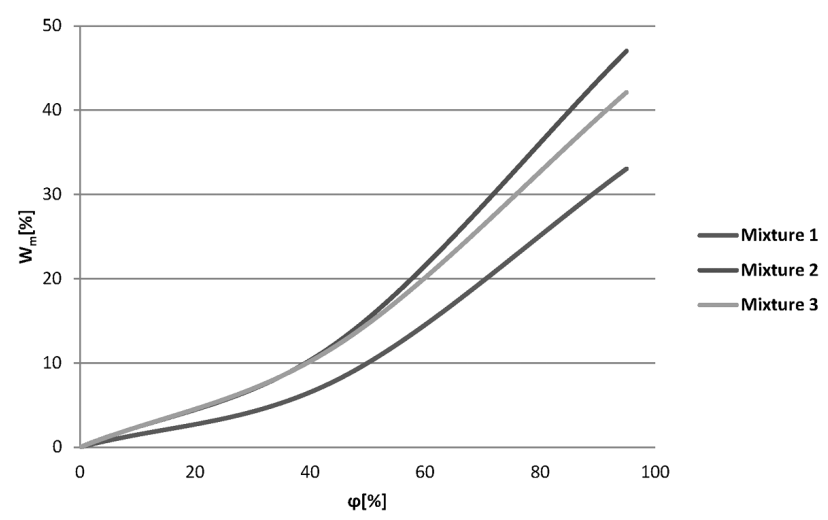

Figure 2: Moisture content $w_{\mathrm{m}}$ for the samples depending on relative humidity $\varphi$ at the temperature of $23{ }^{\circ} \mathrm{C}$

Slika 2: Vsebnost vlage $w_{\mathrm{m}} \mathrm{v}$ vzorcih, $\mathrm{v}$ odvisnosti od relativne vlažnosti $\varphi$ pri temperaturi $23{ }^{\circ} \mathrm{C}$ 


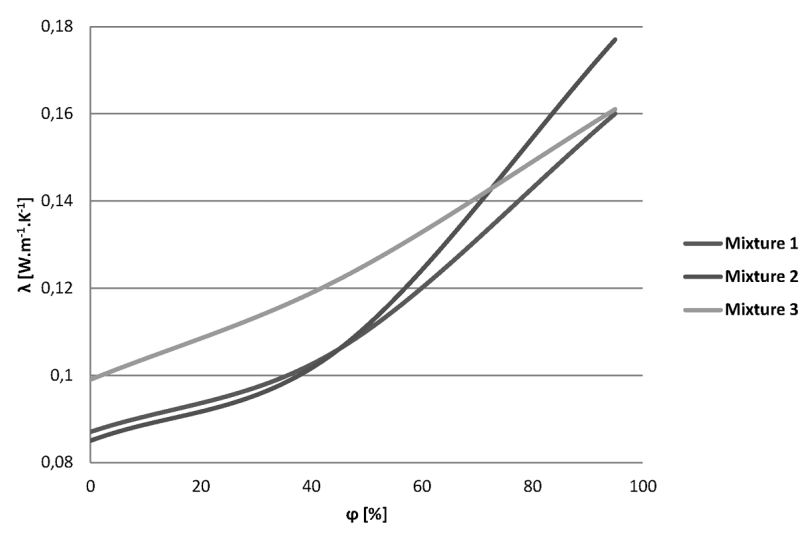

Figure 3: Dependence of thermal conductivity $\lambda$ on relative humidity $\varphi$ Slika 3: Odvisnost toplotne prevodnosti $\lambda$ od relativne vlažnosti $\varphi$

accordance with EN $12667^{11}$ and ISO 8301.12 The measurement was carried out at the natural weight moisture content state, at dry and at moist state. The results are listed in Table $\mathbf{4}$ and Figure 3.

Table 4: Thermal conductivity $\lambda$ in dependence on relative humidity $\varphi$ Tabela 4: Toplotna prevodnost $\lambda$ v odvisnosti od relativne vlažnosti $\varphi$

\begin{tabular}{|c|c|c|c|c|}
\hline $\begin{array}{c}\text { Mixture } \\
\text { No. }\end{array}$ & $\varphi / \%$ & 0 & 50 & 95 \\
\hline \multirow{2}{*}{1} & $w_{\mathrm{m}} / \%$ & 0 & 8.10 & 33.04 \\
\cline { 2 - 5 } & $\lambda\left(\mathrm{W} \mathrm{m}^{-1} \mathrm{~K}^{-1}\right)$ & 0.087 & 0.106 & 0.160 \\
\hline \multirow{2}{*}{2} & $w_{\mathrm{m}} / \%$ & 0 & 12.57 & 47.00 \\
\cline { 2 - 5 } & $\lambda\left(\mathrm{W} \mathrm{m}^{-1} \mathrm{~K}^{-1}\right)$ & 0.085 & 0.106 & 0.177 \\
\hline \multirow{2}{*}{3} & $w_{\mathrm{m}} / \%$ & 0 & 12.23 & 42.11 \\
\cline { 2 - 5 } & $\lambda\left(\mathrm{W} \mathrm{m}^{-1} \mathrm{~K}^{-1}\right)$ & 0.099 & 0.122 & 0.161 \\
\hline
\end{tabular}

As Figure 3 indicates, the thermal conductivity depends on the relative humidity; as its value increases, the value of the thermal conductivity increases as well. This is most apparent for the specimens containing the organic cotton-plant filler. Among the specimens containing rice stems, the thermal conductivity in the damp condition significantly increased for specimen 2 with a lower content of binder and a higher porosity (it is possible to see it in the area where the relative humidity was above $50 \%$ ). Next, the dynamic stiffness of the material was tested using the resonance method in accordance with ISO 9052-1. ${ }^{13}$ The measured values are listed in Table 5, including the category pad and acoustic-material group. ${ }^{16}$

Table 5: Summary of dynamic stiffness $s$,

Tabela 5: Povzetek dinamične togosti $s$

\begin{tabular}{|c|c|c|c|}
\hline $\begin{array}{c}\text { Mixture } \\
\text { No. }\end{array}$ & $\begin{array}{c}s^{\prime} \\
\left(\mathrm{MPa} \mathrm{m}^{-1}\right)\end{array}$ & $\begin{array}{c}\text { Category } \\
\text { pad }^{*}\end{array}$ & $\begin{array}{c}\text { Acoustic-insulation } \\
\text { properties }^{*}\end{array}$ \\
\hline 1 & 10.91 & Category I & Dynamically soft \\
\hline 2 & 13.15 & Category I & Dynamically soft \\
\hline 3 & 12.47 & Category I & Dynamically soft \\
\hline
\end{tabular}

* according to CSN $730532^{16}$

It can be assumed from the obtained values that all the specimens have good acoustic-insulation properties in terms of the impact sound and can be classified as the group of dynamically soft acoustic-insulation materials for which $s^{\prime} \leq 30 \mathrm{MPa} \mathrm{m}^{-1}$ applies. Considering the dynamic-stiffness values, the materials can be used as impact-sound insulators. Finally, the sound-absorption coefficient was determined. The measurement was carried out using an acoustic resonator in accordance with ISO $10534-1^{15}$ and from the obtained values the weighted sound-absorption coefficient $\alpha_{\mathrm{w}}$ was calculated in line with EN ISO 11654. ${ }^{14}$ The resulting values are in Table 6, listing different sound-absorption categories.

Table 6: Weighted sound-absorption coefficient $\alpha_{\mathrm{W}}$ for the frequency of $500 \mathrm{~Hz}$

Tabela 6: Izmerjeni koeficient vpijanja zvoka $\alpha_{\mathrm{w}}$ pri frekvenci $500 \mathrm{~Hz}$

\begin{tabular}{|c|c|c|}
\hline Mixture No. & $\alpha_{\mathrm{w}}(-)$ & $\begin{array}{c}\text { Class of sound } \\
\text { absorption }\end{array}$ \\
\hline 1 & 0.75 & $\mathrm{C}$ \\
\hline 2 & 0.80 & $\mathrm{~B}$ \\
\hline 3 & 0.90 & $\mathrm{~A}$ \\
\hline
\end{tabular}

It is clear from Table 6 that the highest value of the weighted sound absorption was found for specimen 3 , with the cotton-plant stems. Among the samples containing the rice-plant stems, specimen 2, with a higher amount of organic fillers and a reduced binder amount, has higher values.

\section{CONCLUSION}

The research into the possibility of using agricultural waste from the rice and cotton production brought interesting findings for the production of thermal and acoustic-insulation materials. The structure of the specimens was very porous as the coarse fractions of cotton and rice stems form an open porous system. The developed materials reached good values of the thermal conductivity, which can be influenced by increasing or reducing the amounts of the fillers or the binders. The amount of water glass must be chosen according to the need for activating the slag used. The thermal-conductivity value is also influenced by the sensitivity of the material to the relative humidity. In terms of the acoustic properties, the materials acted as good sound absorbers. Especially the porous structure created by cotton stems exhibited high values of the sound-absorption coefficient. To find the optimum formula for the lowest possible values of the thermal conductivity and good acoustic properties while maintaining a sufficient material consistency is the task for further research. The specimens also exhibited very good properties from the point of view of dynamic stiffness. All the samples can be classified as dynamic soft insulation materials.

With respect to the hygrothermal transport, it was found that these materials are sensitive to humidity; under normal conditions, they exhibit sorptive moisture comparable with wood. With a higher moisture content, the thermal insulating properties of these materials 


\section{J. ZACH et al.: STUDY OF THE PROPERTIES AND HYGROTHERMAL BEHAVIOUR ...}

degrade; however, a more significant degradation occurs in the environments with a higher humidity. It can, therefore, be stated that as long as these insulators (e.g., in the form of ETICS) are not exposed to a very high humidity or direct weather actions, they are able to function within the structure and can be successfully applied in many developing countries where they can provide protection not only from the negative effects of cold but also from the high temperatures during the summer (Central Asia, for instance). The research confirmed that binding by means of a slag-based alkali-activated binder could result in a very good ratio between the thermal insulation and mechanical properties. On the contrary, for instance, alkali-bound insulators obtained simply by being pressed or bound by means of bicomponent fibres, can be used in the structures with a lower mechanical load, putting relatively low demands on the production technology and for this reason, they can find use also in industrially less developed countries. ${ }^{2,9}$

\section{Acknowledgements}

This paper was elaborated with the financial support of the projects GA 13-21791S and project No. LO1408 "AdMaS UP - Advanced Materials, Structures and Technologies", supported by Ministry of Education, Youth and Sports under the "National Sustainability Programme I".

\section{REFERENCES}

${ }^{1}$ K. W. Corscadden, J. N. Biggs, D. K. Stiles, Sheep's wool insulation: A sustainable alternative use for a renewable resource?, Resources, Conservation and Recycling, 86 (2014), 9-15, doi:10.1016/ j.resconrec.2014.01.004

${ }^{2}$ K. Wei, C. Lv, M. Chen, X. Zhou, Z. Dai, D. Shen, Development and performance evaluation of a new thermal insulation material from rice straw using high frequency hot-pressing, Energy and Buildings, 87 (2015) 1, 116-122, doi:10.1016/j.enbuild.2014.11.026
${ }^{3}$ D. P. L. Murphy, H. Behring, Arable crop materials for insulation in buildings, Biomass for Energy and Industry, 10th European Conference and Technology Exhibition on Biomass for Energy and Industry, Würzburg, 1998, 176-179

${ }^{4}$ W. D. Brouwer, Natural fibre composites: Where can flax compete with glass?, Sample Journal, 36 (2000) 6, 18-23

${ }^{5}$ S. A. Ibraheem, A. Ali, A. Khalina, Development of Green Insulation Boards from Kenaf Fibres, Part 2: Characterizations of Thermal and Water Absorption, Key Engineering Materials, 462-463 (2011), 1331-1336, doi:10.4028/www.scientific.net/KEM.462-463. 1331

${ }^{6}$ S. A. Ibraheem, A. Ali, A. Khalina, Development of Green Insulation Boards from Kenaf Fibres, Part 1: Development and Characterizations of Mechanical Properties, Key Engineering Materials, 462-463 (2011), 1343-1348, doi:10.4028/www.scientific.net/KEM.462-463. 1343

${ }^{7}$ S. Mukhopadhyay, D. Annamalai, R. Srikanta, Coir Fiber for Heat Insulation, Journal of Natural Fibers, 8 (2011) 1, 48-58, doi:10.1080/ 15440478.2010.551001

${ }^{8}$ S. A. Ibraheem, A. Ali, A. Khalina, Development of Green Insulation Boards from Kenaf Fibres and Polyurethane, Polymer-Plastics Technology and Engineering, 50 (2011) 6, 613-621, doi:10.1080/ 03602559.2010.551379

${ }^{9}$ A. Korjenic, V. Petránek, J. Zach, J. Hroudová, Development and performance evaluation of natural thermal-insulation materials composed of renewable resources, Energy and Buildings, 43 (2011) 9, 2518-2523, doi:10.1016/j.enbuild.2011.06.012

${ }^{10}$ EN 1602 Thermal insulating products for building applications Determination of the apparent density, 2013

${ }^{11}$ EN 12667 Thermal performance of building materials and products Determination of thermal resistance by means of guarded hot plate and heat flow meter methods - Products of high and medium thermal resistance, 2001

${ }^{12}$ ISO 8301 Thermal insulation - Determination of steady-state thermal resistance and related properties - Heat flow meter apparatus, 2010

${ }^{13}$ ISO 9052-1 Acoustics - Determination of dynamic stiffness - Part 1: Materials used under floating floors in dwellings, 1989, reviewed in 2011

${ }^{14}$ EN ISO 11654 Acoustics - Sound absorbers for use in buildings Rating of sound absorption, 1997

${ }^{15}$ ISO 10534-1 Acoustics - Determination of sound absorption coefficient and impedance in impedance tubes - Part 1: Method using standing wave ratio, 1996, reviewed in 2011

${ }^{16}$ ČSN 730532 Acoustics - Protection against noise in buildings and evaluation of acoustic properties of building elements - Requirements, 2010 